\title{
Tutkimus inkoatiivisista tunneverbeistä ja niiden rektioista
}

\begin{abstract}
Maximilian Murmann: Inchoative emotion verbs in Finnish. Argument structures and collexemes. Department of Finnish, FinnoUgrian and Scandinavian Studies. University of Helsinki. $196 \mathrm{~s}$. ja liitteet $17 \mathrm{~s}$. ISBN 978-951-51-4191-0. Väitöskirjan tiivistelmä on luettavissa osoitteessa https://helda. helsinki.fi/handle/10138/233975. ${ }^{1}$
\end{abstract}

Maximilian Murmannin huhtikuussa 2018 tarkastetun väitöskirjan aiheena ovat suomen kielen inkoatiiviset tunneverbit, jotka ilmaisevat erilaisten tunnetilojen alkamista. Tällaisia verbejä ovat esimerkiksi $y l$ lättyä, ilahtua, rakastua ja suuttua. Useimmat inkoatiiviset tunneverbit sisältävät Ujohtimen, ja vanhastaan niitä on morfologisin perustein kutsuttu refleksiivisiksi, vaikka niiden ensisijainen merkitystehtävä onkin lähinnä automatiivinen tai (toisin termein) antikausatiivinen.

Murmannin tutkimuksen kohteena on kyseisten verbien syntaksi ja semantiikka sekä erityisesti verbien taipumus esiintyä niille ominaisissa argumenttirakennekonstruktioissa. Näihin konstruktioihin kuuluu verbin lisäksi tunnetilan aiheuttavaa ärsykettä ilmaiseva, usein paikallissijainen substantiivilauseke, esimerkiksi yllättyä jostakin, ihastua johonkin, suuttua jollekulle. Syntaktisesti tällainen lauseke on rektioadverbiaali tai Ison suomen kieliopin (ISK $2004 \$ 1225$ ) termein rektiotäydennys. Rektiotäydennyksen sija vaihtelee verbeittäin. Esimerkiksi

1. Teoksesta on ilmestymässä päivitetty versio (ks. Murmann tulossa). rakastua hyväksyy vain illatiivi- ja yllättyä elatiivimuotoisen täydennyksen, kun taas hermostua kelpuuttaa molemmat ja lisäksi allatiivin (hermostua jostakin, hermostua johonkin, hermostua jollekulle). Allatiivi on tällaisissa yhteyksissä erikoistunut ilmaisemaan elollisia tarkoitteita, joihin tunnereaktio kohdistuu (hermostua koiralle mutta ${ }^{\star}$ hermostua sotkulle). Sisäpaikallissijat illatiivi ja etenkin elatiivi taas ilmaisevat laajaa kirjoa erilaisia ärsykkeitä, jotka joko laukaisevat tunnetilan muutoksen tai joihin tunnetilan muutos muuten kohdistuu. Ainakin verbit hämmästyä ja pelästyä sallivat paikallissijaisten rektiotäydennysten lisäksi partitiivimuotoisen ärsykkeen ilmauksen, joka perinteisen lauseenjäsennyksen mukaan on objekti (hämmästyä pelästyä jotakin). Rektiosijan valinta on pitkälti idiosynkraattista eikä mitenkään ilmeisellä tavalla motivoidu paikallissijojen spatiaalisista (tai muista) perusmerkityksistä.

Murmannin tutkimusaihe on mielenkiintoinen ja ajankohtainen paitsi fennistiikalle yleisesti myös esimerkiksi S2opetukselle, jossa rektiot joudutaan opettelemaan ulkoa verbi kerrallaan. Voitaisiinko löytää yleisempiä semanttisia periaatteita, jotka motivoivat tietyn sijan esiintymistä tietyn verbin yhteydessä? Aihepiiriä on yllättävää kyllä tutkittu fennistiikassa melko vähän. Lähimpänä Murmannin aihetta on Mari Siiroisen (2001) väitöstutkimus eräistä tunnekausatiiviverbeistä (erityisesti pelätä ja pelottaa), ja Siiroisen työtä Murmann siteeraakin ahkerasti. Hän on muutenkin pereh- 
tynyt hyvin aihepiirin aiempaan fennistiseen kirjallisuuteen, ja hänen työnsä keskustelee sujuvasti tradition kanssa tuoden selvästi esiin, mitä aiemmin on saavutettu ja mitä on vielä tutkimatta.

Työn alkupuolen johdanto- ja teoriaosassa esitellään tutkimusasetelma ja tutkimuksen tavoitteet (luku 1) sekä käsitellään melko laajasti tunteiden kielellistä ilmaisemista ja tätä koskevaa lingvististä tutkimusta mutta myös psykologian piirissä harjoitettua tunteiden ja tunnetilojen tutkimusta (luku 2). Tämä on perusteltua kognitiivisen kielitieteen keskeisiin ajatuksiin sitoutuvassa työssä, etenkin kun juuri psykologiasta omaksutut kategoriat toimivat perustana verbien semanttiselle luokittelulle myös aineistonkäsittelyluvuissa (erityisesti luvussa 6). Analyysin taustoituksena käytetään myös Anna Wierzbickan (esim. 1996) kehittämää alkusanakieltä (natural semantic metalanguage, NSM) sekä mallia suomen kieleen soveltavaa Seija Tuovilan (2005) tutkimusta tunnesanojen semantiikasta.

Kritiikkiä voi esittää kielitypologisen, argumenttirakenteita ja argumenttien merkintää koskevan tutkimuksen vähäisestä hyödyntämisestä. Psykologisia tiloja ja tilanmuutoksia kielentävien ilmausten typologisessa tutkimuksessa päähuomio on kiinnittynyt elollisen osallistujan (kokijan) kielelliseen koodaamiseen, jota on tarkasteltu esimerkiksi siitä näkökulmasta, missä määrin kokija kontrolloi tilannetta tai on siinä vaikutuksenalainen (esim. Croft 1993; Bossong 1998; Haspelmath 2001; Onishi 2001; Næss 2007). Paljon vähemmälle huomiolle on jäänyt aistimuksen tai psykologisen kokemuksen aiheuttavan ärsykkeen kielellinen koodaus. Ärsykkeen ilmausten perusteellinen tutkiminen yhdestä kielestä onkin Murmannin työn merkittävin anti myös yleislingvistiseltä kannalta.

Teoriaosaan kuuluvat myös luku 3, joka käsittelee työssä käytettyjä syntakti- sia malleja, etenkin valenssiteoriaa ja erilaisia argumenttirakenteiden kuvausmalleja, sekä luku 4, joka esittelee aineiston analyysissa hyödynnettyjä korpuslingvistisiä malleja. Tältä osin tarkastelu pohjautuu kehittyneisiin tilastollisen lingvistiikan ja korpustutkimuksen menetelmiin, erityisesti niin sanottuihin kollostruktionaalisiin lähestymistapoihin kuuluvaan yhteisesiintymien kovarianssi-analyysiin (engl. covarying collexeme analysis).

Aineistonsa eli inkoatiivisten tunneverbien esiintymät Murmann on kerännyt Kielipankin Suomi24-korpuksesta. Eri tunneverbien frekvenssien toteamisen jälkeen tarkempi tutkimus rajataan kahteenkymmeneen yleisimpään verbiin, niiden argumenttirakenteisiin sekä verbien kollokaatteina tyypillisesti esiintyviin substantiiveihin. Argumenttirakenteita tarkastelemalla (luku 5) saadaan selville, minkä muotoiset lausekkeet voivat esiintyä tarkasteltavien verbien kuvaaman tunnereaktion ärsykettä ilmaisemassa. Luvun 6 kollokaattianalyysissa taas selvitetään sitä, millaiset tunnetilan aiheuttavaa ärsykettä ilmaisevat substantiivit ovat tyypillisiä kunkin verbin yhteydessä.

Korpuslingvististen menetelmien valinta ja käyttö on kaikkiaan perusteltu hyvin, ja epäilemättä suureen työmäärään pohjaava analyysi on kauttaaltaan huolellista. Hienoista kritiikkiä voi esittää siitä, millaisin kriteerein kollokaatiot on korpuksesta haettu ja määritelty (tätä esitellään alaluvussa 4.3). Murmann on nimittäin ottanut aineistoonsa mukaan vain sellaisia verbin ja ärsykettä ilmaisevan substantiivin myötäesiintymiä, joissa substantiivi sijaitsee välittömästi verbin jäljessä. Analyysista ovat näin jääneet pois esimerkiksi tapaukset, joissa verbin ja substantiivin välissä on substantiivia määrittävä, tämän kanssa samaan lausekkeeseen kuuluva attribuutti. Vastaamatta jää myös kysymys, millaisia olisivat ne ärsykeilmaukset, jotka välittömän vierekkäisyyden vaatimus jättää analyysin ulkopuo- 
lelle, siis ne ärsykeilmaukset, jotka syystä tai toisesta sijaitsevat muualla kuin välittömästi verbin jäljessä.

Luvussa 5 tarkastellaan aineiston 20 frekventeimmän inkoatiivisen tunneverbin tyypillisiä ärsykeilmauksia muodon kannalta. Jokaista verbiä kohden on satunnaisesti valittu sata lause-esiintymää tarkemmin analysoitaviksi. Luku etenee ärsykeilmausten rakenteen (lähinnä sijamuodon) mukaan: erikseen tarkastellaan partitiivi-, elatiivi-, illatiivi- ja allatiivimuotoisia substantiivilausekkeita, kokonaisen lauseen laajuisia ilmauksia, eifiniittisiä komplementteja sekä eräitä harvinaisempia rakenteita. Luvun 5 laskelmissa on otettu huomioon omana rakennemallinaan myös sellaiset tapaukset, joista ilmipantu rektiotäydennys puuttuu. Taulukon 29 (s. 80) perusteella rektiotäydennyksen puuttuminen on varsin yleinen ja eräille inkoatiivisille tunneverbeille (mm. ahdistua, masentua ja pettyä) jopa kaikkein yleisin esiintymiskonteksti. Luku 5 antaakin hyvän kokonaiskuvan siitä, minkämuotoisten ärsykeilmausten kanssa kukin verbi esiintyy.

Luvussa 6 esitellään semanttisin kriteerein ryhmiteltyinä tarkemman analyysin kohteeksi valitut 20 verbiä sekä niiden kanssa kollokoivat substantiivit. Analyysi on kauttaaltaan huolellista, ja rektiomääritteen paikallissijan määräytymisestä tehdään oivaltavia havaintoja. Tarkastelluista paikallissijoista allatiivi erottuu muista selvimmin, sillä sen päätehtävänä on ilmaista (laajassa mielessä) elollista osallistujaa, johon tunnereaktio kohdistuu (esimerkiksi suutuin hänelle; matkustaja raivostui lentoyhtiölle). Illatiivin ja elatiivin tehtävät taas näyttävät lankeavan enemmän yhteen, eikä niiden välinen mahdollinen merkitysero ole aina mitenkään selvä kaikkien sellaisten verbien yhteydessä, jotka sallivat molemmat sijamuodot (hermostua kyselystä vs. kyselyyn).

Erittäin mielenkiintoinen on toisaalta Murmannin tekemä havainto, jonka mu- kaan illatiivia käytetään usein sellaisista ärsykkeistä, joille kokija on altistunut jo ennen varsinaista tunnetilan muutosta. Tämä periaate ilmenee eräiden sellaisten verbien pakollisena illatiivirektiona, jotka nimenomaan ilmaisevat kokijan aiempaa altistumista ärsykkeelle (kyllästyä tai pettyä johonkin, ehkä myös rakastua johonkuhun); vastaavasti äkillistä ärsykkeestä tietoiseksi tulemista kuvaavat verbit järjestyvät yleensä elatiivin kanssa (yllättyä, hämmästyä, ilahtua jostakin). Silloinkin, kun yksi ja sama verbi sallii sekä illatiivin että elatiivin, näiden välillä voi esiintyä samantapainen merkitysero: hermostutaan yhtäältä jahkailuun tai odottamiseen (ärsykkeille on altistuttu jo ennen itse hermostumista), toisaalta provosoinnista tai kysymyksestä (ärsykkeet kohdataan äkillisesti). Ero ei ole ehdoton eikä kaikenkattava, mutta se tarjoaa osaltaan yhden semanttisen selityspohjan verbilekseemien rektioeroille ja myös yhden ja saman verbilekseemin sallimalle rektiotäydennyksen sijanvaihtelulle.

Maximilian Murmannin väitöskirja sisältää runsaasti uutta ja mielenkiintoista tutkimustietoa tärkeästä syntaktissemanttisesta alueesta, joka aiemmassa fennistisessä tutkimuksessa on jäänyt melko vähälle huomiolle. Työn pohjana on hyvin toteutettu, suuritöinen korpusanalyysi, jonka avulla saadaan selvitettyä etenkin sitä, millaisissa argumenttirakennekonstruktioissa ja millaisten kollokaattien seurassa verbit esiintyvät aidossa kielenkäytössä. Väitöskirja sisältää arvokkaita havaintoja siitä, miten rektioadverbiaalin sijanvaihtelu joskus ilmentää melko selviäkin semanttisia oppositioita yhtäältä eri verbilekseemien välillä ja toisaalta sellaisten verbilekseemien eri argumenttirakennekonstruktioiden välillä, jotka sallivat rektiosijan vaihtelua. Työllä on runsaasti mielenkiintoista annettavaa myös virolaiselle lukijalle, sillä virossa esiintyy periaatteiltaan hyvin samantapaista vaihtelua ärsykeilmausten koodauksessa, mutta 
useiden yhtäläisyyksien lisäksi myös eroja suomen vastaaviin ilmauksiin. Toivoa sopii myös, että Murmannin tutkimuksessa esille nousseita havaintoja hyödynnettäisiin rektiosijojen S2-opetuksessa. Kielentutkijaa nämä havainnot rohkaisevat jatkopohdintoihin siitä, voisiko suomen tai viron rektioilmiöille olla löydettävissä laajempaakin semanttista motivaatiota.

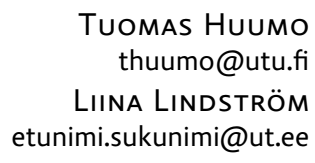

Tuomas Huumo on Turun yliopiston suomen kielen professori. Liina Lindström on Tarton yliopiston viron kielen dosentti. Hän toimi Murmannin vastaväittäjänä.

\section{Lähteet}

Bossong, GeOrg 1998: Le marquage de l'expérient dans les langues d'Europe. Jack Feuillet (toim.), Actance et valence dans les langues de l'Europe s. 259-294. Berlin: De Gruyter.

Croft, William 1993: Case marking and the semantics of mental verbs. - James Pustejovsky (toim.), Semantics and the lexicon s. 55-72. Boston: Kluwer Academic Publishers.

Haspelmath, Martin 2001: Noncanonical marking of core arguments in European languages. - Alexandra Y.
Aikhenvald, R.M. W. Dixon \& Masayuki Onishi (toim.), Non-canonical marking of subjects and objects s. 53-84. Amsterdam: Benjamins.

ISK = Hakulinen, AUli - Vilkuna,

Maria - Korhonen, Rittta -

Koivisto, Vesa - Heinonen Tarja

Rittta - Alho, Irja 2004: Iso suomen kielioppi. Verkkoversio. Helsinki: Suomalaisen Kirjallisuuden Seura. http:// scripta.kotus.fi/visk (10.11.2018).

Murmann, Maximilian (tulossa): Inchoative emotion verbs in Finnish. Argument structures and collexemes. Tübingen: Narr France Attempto Verlag.

NÆSs, ÅSHILD 2007: Prototypical transitivity. Amsterdam: John Benjamins.

Onishi, Masayuri. 2001: Non-canonically marked subjects and objects: Parameters and properties. - Alexandra Y. Aikhenvald, R. M. W. Dixon \& Masayuki Onishi (toim.), Non-canonical marking of subjects and objects s. 1-51. Amsterdam: Benjamins.

Sirroinen, Mari 2001: Kuka pelkää ja ketä pelottaa? Nykysuomen tunneverbien kielioppia ja semantiikkaa. Helsinki: Suomalaisen Kirjallisuuden Seura.

Tuovila, Seija 2005: Kun on tunteet. Suomen kielen tunnesanojen semantiikkaa. Oulu: Oulu University Press.

Wierzbicka, Anna 1996: Semantics. Primes and universals. Oxford: Oxford University Press.

\section{Kun futuuria ei ole}

Mila Karttunen: No pittää kahttoo. Puhujan tulevan toiminnan ilmausten kielioppia ja pragmatiikkaa. Publications of the University of Eastern Finland. Dissertations in Education, Humanities, and Theology 119. Joensuu: Itä-Suomen yliopisto 2018. $256 \mathrm{~s}$. ISBN 978-952-61-2711-8.
Miia Karttusen väitöstutkimus koskee puhujan tulevan toiminnan ilmauksia suomen kielessä. Suomessahan varsinaista futuuritempusta ei ole, mutta futuurisia ilmauksia on fennistiikassa jonkin verran kuvattu osana laajempaa tempusjärjestelmän kuvausta (esim. Ikola 1949; Wiik 1976; 